\title{
STUDI KASUS INFEKSI TILAPIA LAKE VIRUS (TiLV) PADA IKAN NILA (Oreochromis niloticus)
}

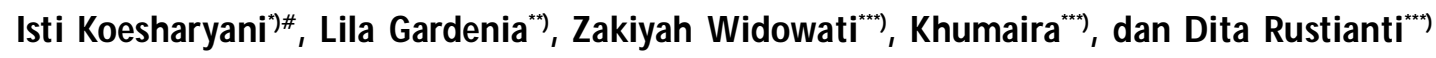 \\ *) Pusat Riset Perikanan \\ * Balai Riset Perikanan Budidaya Air Tawar dan Penyuluhan Perikanan \\ ***) Balai Uji Standar Karantina Ikan
}

(Naskah diterima: 11 Desember 2017; Revisi final: 29 Januari 2018; Disetujui publikasi: 29 Januari 2018)

\begin{abstract}
ABSTRAK
Ikan nila atau Oreochromis niloticus merupakan ikan konsumsi masyarakat di Indonesia. Kasus kematian massal ikan nila terjadi di beberapa lokasi budaya di Jawa, Lombok, dan Sumatera yang disebabkan oleh infeksi Orthomyxovirus, dan disebut sebagai Tilapia Lake Virus (TiLV). Tujuan penelitian ini adalah untuk mendeteksi adanya infeksi TiLV dengan metode semi-nested Reverse Transcriptase-Polymerase Chain Reaction (RT-PCR) pada kasus kematian massal ikan nila. Lokasi pengambilan sampel di Desa Sigerongan Kecamatan Lingsar, Lombok, Nusa Tenggara Barat. Analisis deteksi RT-PCR menggunakan sampel organ otak, ginjal, limpa, dan hati, selanjutnya dilakukan sekuensing. Hasil pengamatan terhadap gejala klinis terhadap ikan nila moribund terlihat kondisi mata yang buram/katarak, serta cekung, abrasi kulit, serta perubahan warna tubuh menjadi lebih gelap. Hasil analisis RT-PCR menunjukkan bahwa kejadian kematian massal pada ikan nila suspektif diakibatkan oleh infeksi RNA virus TiLV. Analisis sekuensing menunjukkan bahwa TiLV dari sampel ikan nila di Lombok mempunyai kesamaan identitas genetik 97\%dengan TiLV asal Israel (Genebank Accession Number KU 751816.1).
\end{abstract}

\section{KATA KUNCl: $\quad$ nila; TiLV; seminested RT-PCR}

ABSTRACT: Case study of tilapia lake virus (TiLV) infection on nila (Oreochromis niloticus). By: Isti Koesharyani, Lila Gardenia, Zakiyah Widowati, Khumaira, and Dita Rustianti

Oreochromis niloticus is the main consumption fish commodity in Indonesia. The mortality cases of Nile tilapia have occurred in several culture sites in Java, Lombok, and Sumatra due to the infection of Orthomyxovirus, Tilapia Lake Virus (TiLV). The purpose of this study was to detect the presence of TiLV infection in mass mortality case of Nile tilapia culture using the semi-nested Reverse Transcriptase-Polymerase Chain Reaction (RT-PCR). Fish samples were sourced from Segerongan Village Lingsar District, Lombok, West Nusa Tenggara. For RT-PCR analysis, samples from fish brain, kidney, spleen, and liver were collected and treated for sequencing analysis. The visual observation on the moribund tilapia had found several specific clinical symptoms such as eye cataract with sunken eyes, skin abrasion, and darkened body coloration. The result of RT-PCR analysis showed that mass mortalities of tilapia fish had been suspective caused by the infection TiLV RNA virus. The sequencing analysis showed that TiLV samples from Lombok have a genetic similarity of $97 \%$ with TiLV from Israeli (Genebank Accession Number KU 751816.1).

\section{KEYWORDS: nile tilapia; TiLV; seminested RT-PCR}

\section{PENDAHULUAN}

Ikan nila Oreochromis niloticus merupakan jenis ikan air tawar yang diintroduksi dari Afrika bagian timur pada tahun 1969. Ikan ini menjadi ikan budidaya yang populer di kolam-kolam air tawar di Indonesia. Produksi ikan nila di Indonesia terus meningkat sejak tahun 2009, yaitu mencapai 99.969 ton. Menurut

\footnotetext{
\# Korespondensi: Pusat Riset Perikanan. Gedung BRSDMKP 2, J.. Pasir Putih II No. 2, Ancol Timur, Jakarta Utara 14430, Indonesia.

Tel. + 622164700928

E-mail: istisugama@yahoo.com
}

Jansen \& Mohan (2017), produksi global dari ikan nila diperkirakan mencapai 6,4 juta metrik ton (MMT) dan pada tahun 2015. Ada tiga produsen nila terbesar yaitu Republik Rakyat Cina dari Cina (1,78 MMT), Indonesia (1,12 MMT), dan Mesir (0,88 MMT) (FAO, 2017a). Bangladesh, Vietnam, dan Filipina adalah produsen terkemuka lainnya. Menurut data produksi di Direktorat Jenderal Perikanan Budidaya (DJPB) KKP, produksi ikan nila di Indonesia sejak tahun 2013 meningkat dari 914,78 ribu ton menjadi 999,64 ribu ton pada tahun 2014, kemudian pada tahun 2015 produksi nila mencapai 1,084 juta ton dengan nilai 
ekspor sebesar 14,681 ton tetapi nilai ekspor menurun menjadi 11,879 ton pada tahun 2016. Kondisi penurunan ini kemungkinan ada hubungannya dengan kasus kematian massal akibat penyakit. Pada tahun 2016 kasus kematian massal terpantau terjadi di pembudidaya ikan di Lombok, dengan gejala menyerupai kasus infeksi virus TiLV yang pernah terjadi di Israel. Kondisi ini perlu diwaspadai karena saat ini bibit atau benih nila selain dari lokal juga diimpor dari beberapa negara lain seperti dari Thailand, Filipina, dan Amerika. Kegiatan impor benih sering menimbulkan masalah karena akan disertai pula impor penyakit. Kasus ini sama seperti kasus impor ikan hias yang juga disertai masuknya penyakit baru yang pada awalnya belum ada di Indonesia seperti Koiherpes virus (KHV) (Sunarto \& Cameron, 2006). Hal yang sama juga terjadi kasus penyakit udang infectious myonecrosis virus (IMNV) pada budidaya udang di Situbondo, Jawa Timur tahun 2006 (Senapin et al., 2007). Kondisi ini diduga karena adanya kegiatan impor baik benih maupun calon induk yang kurang terawasi. Akhir-akhir ini di beberapa daerah terjadi kasus kematian pada budidaya ikan nila secara massal yang kemungkinan infeksi penyakit TiLV. Virus ini merupakan genus dari famili Orthomyxoviridae, yang mereplikasi di inti sel pada jaringan ikan. TiLV yang pertama kali dilaporkan terjadi di Israel menyebar ke Ekuador dan Kolombia (Eyngor et al., 2014; Bacharach et al., 2016) dan ke beberapa negara seperti Mesir (Fathi et al., 2017 dan Nicholson et al., 2017), Thailand (Dong et al., 2017a; 2017b; Surachetpong et al., 2017), serta India (Behera et al., 2017), serta Malaysia (Amal et al., 2017). Di Indonesia sejak beberapa tahun belakangan ini sering terjadi adanya kasus kematian massal budidaya ikan nila terutama di Sumatera, Jawa, Bali, dan Lombok. Walaupun belum diketahui penyebab kematiannya, namun bila dilihat dari gejala klinis yang terlihat kemungkinan disebabkan oleh adanya infeksi virus. Tujuan penelitian ini adalah mendeteksi adanya infeksi TiLV dengan metode SemiNested Reverse Transcriptase-Polymerase Chain Reaction (RT-PCR) pada kasus kematian massal ikan nila. Dengan demikian, kasus kematian ikan nila yang sering terjadi disentra budidaya dapat dideteksi secara dini agar mempermudah tindakan pencegahan.

\section{BAHAN DAN METODE}

\section{Ikan Nila (Oreochromis niloticus) Uji}

Sampel didapat pada bulan Mei 2016, dengan terjadinya kasus kematian massal ikan nila jenis Anjani di Desa Sigerongan Kecamatan Lingsar, Lombok, Nusa Tenggara Barat. Sampel ikan moribund/mati diambil beberapa organ berupa otak, hati, ginjal, dan limpa, kemudian disimpan dalam alkohol 90\%untuk dilakukan pengujian di laboratorium.

\section{Deteksi TiLV dengan Metode Semi-nested Reverse Transcriptase-Polymease Chain Reaction (RT-PCR)}

Pada masing-masing organ seperti otak, hati, ginjal, dan limpa yang didapat, diekstrak menggunakan Kit RNA solution dari IQ 2000 System, selanjutnya konsentrasi RNA diukur menggunakan Nanodrop. RNA kemudian diamplifikasi menggunakan spesifik primer untuk TiLV. Pasangan primer yang digunakan didesain oleh Eygnor et al. (2014) dan Tsofack et al. (2016), amplifikasi dilakukan secara semi-nested RT-PCR (Dong et al., 2017a). Pada proses semi-nested RT-PCR dilakukan dengan menggunakan primers forward pada amplifikasi pertama. Adapun susunan sekuen primer yang dipakai dapat dilihat pada Tabel 1 .

Amplifikasi pertama (first round) RT-PCR dilakukan dalam total volume $25 \mu \mathrm{L}$, masing-masing sampel menggunakan AMV reverse enzyme 0,5 $\mu \mathrm{L}$; Go Tag Green $12,5 \mu \mathrm{L}$; primers reverse Nested ext-1; dan forward ME1 dengan konsentrasi 10 pMol masing-masing sebanyak $1 \mu \mathrm{L}$, template RNA (100 ng) sebanyak $2 \mu \mathrm{L}$, dan $\mathrm{ddH}_{2} \mathrm{O}$ sebanyak $8 \mu \mathrm{L}$. Kemudian untuk analisis semi-nested, komposisi untuk bahan amplifikasi menggunakan Go Tag Green 12,5 $\mu \mathrm{L}$ dengan total volume $25 \mu \mathrm{L}$, masing-masing sebanyak $1 \mu \mathrm{L}$ primer 7450/150R/ME2 dan ME1, $2 \mu \mathrm{L}$ template c-DNA menggunakan hasil amplifikasi pertama. Amplifikasi dilakukan pada mesin thermalcycler T100 Biorad. Pada siklus amplifikasi RT-PCR pertama dan semi-nested adalah sebagai berikut: untuk proses sintesis c-DNA menggunakan reverseenzymedilakukan pada suhu $50^{\circ} \mathrm{C}$ selama 30 menit, dilanjutkan dengan pre-denaturasi $94^{\circ} \mathrm{C}$ selama dua menit. Kemudian proses amplifikasi dilakukan sebanyak 30 kali siklus, dengan proses denaturasi, anaeling, dan elongasi: masing-masing pada suhu $94^{\circ} \mathrm{C}$ selama 30 detik, $60^{\circ} \mathrm{C}\left(30\right.$ detik), dan $72^{\circ} \mathrm{C}$ (30 detik). Pada proses terminasi digunakan suhu $72^{\circ} \mathrm{C}$ selama tujuh menit. Langkah berikutnya untuk siklus amplifikasi semi-nested menggunakan proses yang sama seperti amplifikasi pertama tetapi tanpa melakukan proses in-aktivasi reverse enzyme. Adapun target berat molekul untuk amplifikasi pertama adalah di $415 \mathrm{bp}$ yang mengindikasikan bahwa sampel tersebut terinfeksi berat dan semi-nested di 250 bp yang merupakan indikator infeksi ringan. Hasil amplifikasi selanjutnya dielektroforesis pada 1,5\%agarose dalam buffer $1 x$ Tris-acetate-EDTA (TAE) dan didokumentasikan dengan gel dokumentasi. 
Tabel 1. Sekuen pasangan primer yang digunakan untuk mendeteksi TiLV dengan metode semi-nested RT PCR pada ikan nila

Table1. The sequence of primer pairs for TiLV detection using the semi-nested RT-PCR on tilapia fish

\begin{tabular}{lcccc}
\hline \multicolumn{1}{c}{ Prime name } & \multicolumn{1}{c}{$\begin{array}{c}\text { Sekuensi } \\
\text { Sequence (5'-3') }\end{array}$} & $\begin{array}{c}\text { Product size } \\
(\mathbf{b p})\end{array}$ & $\begin{array}{c}\text { Referensi } \\
\text { Reference }\end{array}$ \\
\hline Nestedext-1 & TATGCAGTACTTTCCCTGCC & & & Eyngo et al . (2014) \\
\cline { 1 - 2 } ME1 & GTTGGGCACAAGGCATCCTA & & & \\
\hline 7450/150R/ME2 & TATCACGTGCGTACTCGTTCAGT & 250 & Tsofack et al . (2016) \\
\hline
\end{tabular}

\section{Filogenetik dan Similarity Indeks DNA Sekuens TiLV}

Analisis DNA sekuens TiLV dilakukan di Balai Uji Standar Karantina, Badan Karantina Ikan Cilangkap, Jakarta. Sekuensing dilakukan pada bagian segmen 3 dari 10 segmen genom RNA TiLV dengan menggunakan primer ME1 dan Ext1 pada amplikon dengan target panjang segmen 415 bp. Komposisi reaksi sekuensing adalah BDT (2.5X) $2 \mu \mathrm{L}$, Seq Buffer (5X) $3 \mu \mathrm{L}$, Seq primer tunggal $(10 \mu \mathrm{M}) 3.2 \mathrm{pmol}(\approx 1$ $\mu \mathrm{L})$, DNA template $10 \mathrm{ng} / 100 \mathrm{bp}(\approx 1-2 \mu \mathrm{L})$, nuclease free water hingga volume akhir reaksi sebesar $20 \mu \mathrm{L}$, Thermal cycleamplifikasi yang digunakan sesuai dengan Tabel 2. Hasil amplifikasi kemudian dianalisis pada sequencer ABI 3130 CE. Similarity sekuen nukleotida TiLV atau Nucleotide Sequence similarity dilakukan dengan mensejajarkan DNA sekuens pada GenBank dengan program BLASTN database atau nucleotide blast pada (https://blast.ncbi.nlm.nih.gov). Analisis filogenetik sekuen DNA TiLV dari ikan nila di Lombok dilakukan dengan membandingkan DNA sekuens TiLV yang sudah terdaftar di Genbank, menggunakan software Neighbor-joining BIOEDIT M EGA Vesion 7.

\section{HASIL DAN BAHASAN}

Kematian massal ikan nila strain "Anjani" telah terjadi pada bulan Mei 2016 di kelompok pembudidaya
Embung Biru Desa Sigerongan Kecamatan Lingsar Kabupaten Lombok Barat, Nusa Tenggara Barat. Bila dilihat dari gejala klinis ikan yang terinfeksi, serta tingkat kematian ikan yang sangat tinggi $(70 \% 100 \%$ mengindikasikan bahwa kematian massal tersebut terjadi akibat infeksi virus. Adapun secara fisik gejala yang terlihat adalah warna kulit bagian tubuh merubah menjadi lebih gelap atau menghitam, adanya luka pada kulit, pembengkakan rongga perut, sedangkan pada bagian mata mengalami exophtalmia dan buram/katarak (Gambar 1.)

Gejala klinis pada kasus kematian ikan nila di Lombok ini hampir sama seperti pada kasus kematian ikan nila yang terjadi di Israel dan M esir, yaitu adanya kelainan pada mata, letargi atau lemas, serta gejala fisik lain seperti erosi kulit dan kematian massal lebih dari 80\%(Eygnor et al., 2014). Gejala adanya infeksi TiLV di Thailand dilaporkan bahwa ikan nila kehilangan kemauan memangsa pakan, warna tubuh menjadi pucat, berkelompok di dasar bak, pergerakan lamban, tidak aktif, dan pada akhirnya mengalami mortalitas (Dong et al., 2017a). Kasus infeksi TiLV di Asia terutama di Thailand ternyata sudah ada sejak tahun 2012 ditunjukkan dari hasil analisis secara semi-nested RT-PCR, terdapat pada yolk-sac larvae red tilapia. Selain itu, infeksi TiLV ini juga menginfeksi ikan nila pada stadia fingerling (Dong et al., 2017b). Kasus infeksi di

Tabel 2. Siklus suhu amplifikasi untuk DNA sequencing TiLV ikan nila

Table2. Thermal cycle amplification for DNA sequencing of TiLV of tilapia fish

\begin{tabular}{|c|c|c|c|c|c|c|c|c|c|}
\hline \multicolumn{2}{|c|}{$\begin{array}{l}\text { Denaturasi awal } \\
\text { Early denaturation }\end{array}$} & \multicolumn{6}{|c|}{$\begin{array}{l}\text { Kecepatan perubahan suhu } \\
\text { Rapid thermal ramp }\end{array}$} & \multicolumn{2}{|l|}{ Hold } \\
\hline $\begin{array}{c}\text { Suhu } \\
\text { Temperature }\end{array}$ & $\begin{array}{l}\text { Waktu } \\
\text { Time }\end{array}$ & $\begin{array}{c}\text { Suhu } \\
\text { Temperature }\end{array}$ & $\begin{array}{l}\text { Waktu } \\
\text { Time }\end{array}$ & $\begin{array}{c}\text { Suhu } \\
\text { Temperature }\end{array}$ & $\begin{array}{l}\text { Waktu } \\
\text { Time }\end{array}$ & $\begin{array}{c}\text { Suhu } \\
\text { Temperature }\end{array}$ & $\begin{array}{l}\text { Waktu } \\
\text { Time }\end{array}$ & $\begin{array}{c}\text { Suhu } \\
\text { Temperature }\end{array}$ & $\begin{array}{l}\text { Waktu } \\
\text { Time }\end{array}$ \\
\hline \multirow[b]{2}{*}{$96^{\circ} \mathrm{C}$} & \multirow{2}{*}{$\begin{array}{l}1 \text { menit } \\
1 \text { minute }\end{array}$} & \multicolumn{6}{|c|}{25 siklus (25 cycles) } & \multirow[b]{2}{*}{$4^{\circ} \mathrm{C}$} & \multirow[b]{2}{*}{$\sim$} \\
\hline & & $96^{\circ} \mathrm{C}$ & $\begin{array}{l}10 \text { detik } \\
10 \text { second }\end{array}$ & $50^{\circ} \mathrm{C}$ & $\begin{array}{l}5 \text { detik } \\
5 \text { second }\end{array}$ & $60^{\circ} \mathrm{C}$ & $\begin{array}{l}4 \text { menit } \\
4 \text { minute }\end{array}$ & & \\
\hline
\end{tabular}




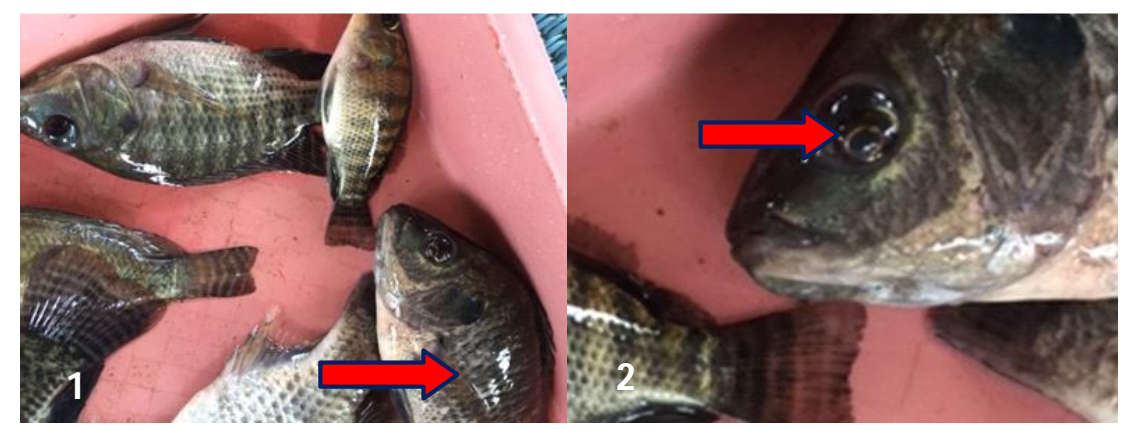

Gambar 1. Gejala klinis infeksi TiLV ikan nila Anjani di Desa Sigerongan Kecamatan Lingsar, Lombok (1. perubahan warna tubuh; 2. kerusakan pada mata).

Figure 1. Clinical symptoms of TiLV infection on nileAnjani strain in Sigerongan Village Lingsar Districk, Lombok (1. changes body coloration; 2. eyes damages).

Lombok terjadi pada ikan nila ukuran $8-12 \mathrm{~cm}$ dan gejala klinis terindikasi infeksi virus dengan adanya kematian massal. Hasil penelitian menunjukkan bahwa dari ke-4 jenis organ yang digunakan sebagai bahan uji ternyata organ otak adalah target infeksi TiLV. Hal ini terbukti dari hasil analisis RT-PCR dengan tampilan elektroforesis menunjukkan bahwa organ otak sudah terdeteksi pada tahap amplifikasi pertama (first round) yaitu terlihat adanya pita DNA yang sesuai target sebesar $415 \mathrm{bp}$. Dengan demikian infeksi virus TiLV lebih banyak terakumulasi dan berkembang di organ otak (Gambar 2). Penelitian yang telah dilakukan menggunakan cell line culture, TiLV ini hanya dapat hidup pada primary tilapia brain cells atau pada kultur sel
E-11 dan cytopathic effect dapat terlihat pada hari ke-5 sampai hari ke-10 post infection. Gambaran sel TiLV pada electron microscopy berbentuk enveloped icosahedral dengan diameter partikel 55-75 nm (Eyngor et al., 2014).

Analisis semi-nested selanjutnya dilakukan untuk menentukan lebih pasti ada tidaknya organ yang terpapar oleh TiLV, mengingat metode tersebut dapat meningkatkan sensitivitas deteksi. Hasil analisis menunjukkan bahwa pada organ hati, ginjal, dan limpa terlihat terjadi infeksi virus TiLV dengan adanya pita DNA dengan berat molekul $250 \mathrm{bp}$. Hal ini merupakan indikasi bahwa TiLV belum banyak berkembang pada

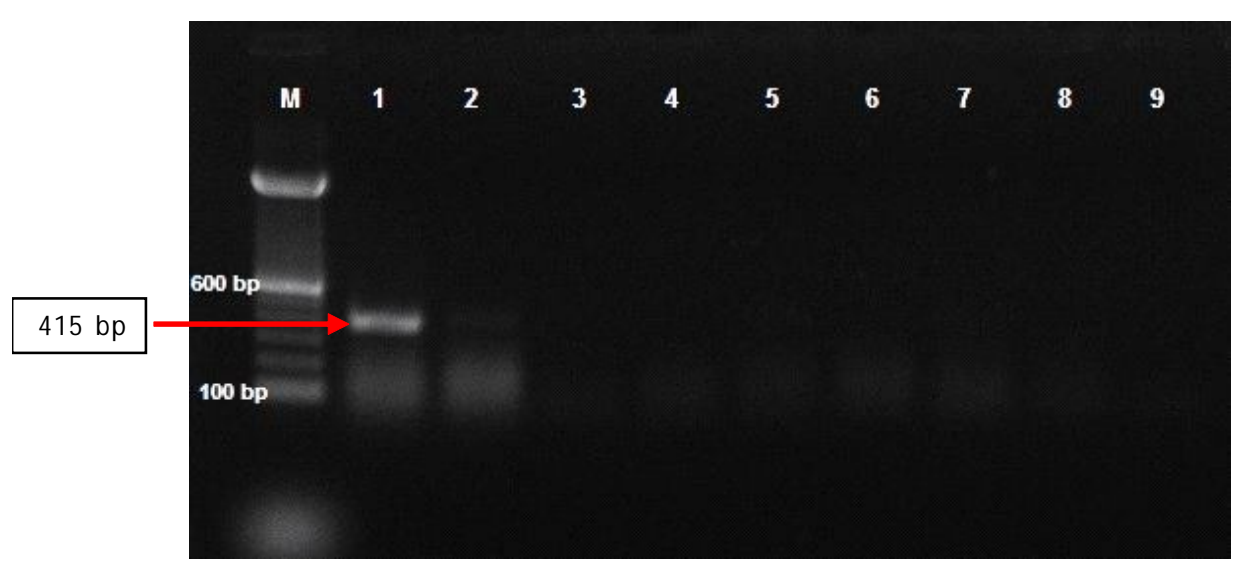

Gambar 2. Hasil amplifikasi pertama RT-PCR nila 0. niloticus strain Anjani dari organ uji yang berbeda ( $1 \& 2$ : otak; $3 \& 4$ : hati; $5 \& 6$ : ginjal; $7 \&$ 8: limpa; 9: negatif kontrol; M: marker 100 bp DNA ladder).

Figure 2. Amplification result on the first round RT-PCR on nile $\mathbf{0}$. niloticus strain Anjani from different organs ( $1 \& 2$ : brain; $3 \& 4$ : heart; $5 \& 6$ : kidney; $7 \& 8$ : spleen; 9: negative controls; $M$ : 100 bp marker of DNA ladder). 
organ-organ tersebut dibandingkan pada otak. Kondisi tersebut dapat memberikan gambaran bahwa pada organ hati, limpa, dan ginjal baru terjadi infeksi awal TiLV. Dengan hasil analisis molekuler menggunakan semi-nested RT PCR menunjukkan bahwa kematian ikan nila 0. niloticus strain Anjani yang terjadi di Lombok secara suspektif disebabkan oleh adanya infeksi TiLV dengan stadium infeksi yang berbeda pada setiap organ (Gambar 3).

Pada deteksi ini tidak menggunakan positif kontrol, tetapi dari hasil analisis menunjukkan bahwa fragmen DNA berada pada target berat molekul 450 $\mathrm{bp}$, sesuai dengan target region primer spesifik yang digunakan. Pada target berat molekul 415 bp menunjukkan bahwa ikan nila positif terinfeksi dengan tingkatan berat, sedangkan pada infeksi ringan DNA hasil amplifikasi terlihat pada berat molekul $250 \mathrm{bp}$. Pengujian semi-nested RT-PCR mempunyai sensitivitas yang lebih baik, seperti dilihat pada Tabel 3 .

Analisis sekuensing dan pilogenetik kekerabatan TiLV dilakukan pada bagian segmen-3 dari 10 segmen genom RNA TiLV, karena segmen-3 ini merupakan pembeda (encode region) dengan genus Orthomyxovirus dari virus Influenza C PB1 yang hanya terdapat pada segmen-1. Dengan demikian, bagian segmen-3 ini digunakan untuk mengetahui sifat atau karakter genetik TiLV ikan nila asal Lombok. Hasil analisis sekuensing dan filogenetik menggunakan primer ME1 dan Ext1 pada amplikon 415 bp yang dianal isis dengan BIOEDIT MEGA Versi 7, menunjukkan bahwa TiLV yang berasal dari Lombok berada dalam satu kluster dengan
TiLV yang berasal dari India (Gambar 4), sehingga dapat dikatakan bahwa TiLV dari ikan nila India dan Lombok mempunyai kekerabatan yang dekat. Berdasarkan analisis similarity antara sekuens DNA dari TiLV ikan nila Lombok yang disejajarkan dengan sekuen DNA pada Gen Bank menunjukkan adanya kesamaan sebesar 97\%dengan TiLV dari Israel (KU 751816 \& KJ 605629), Thailand (KY 381578), dan India (MF 502419 dan MF 582636). Hal ini sesuai dengan pola sebaran TiLV yang berasal dari Israel, ke Asia Timur (India), dan Asia Tenggara (Thailand).

Indonesia yang selama ini masih bergantung pada benih impor terutama dari beberapa Negara Asia untuk memenuhi ekspor fillet nila ke USA dan Eropa ini, sangat memerlukan perhatian terutama dalam Ialu lintas pemasukan ikan nila dari negara asing. Beberapa negara seperti Thailand sudah mendeteksi adanya TiLV sejak tahun 2012 (Dong et al., 2017b) dan Selangor, Malaysia pun sudah diketahui adanya kasus infeksi TiLV (Amal et al., 2017). Nampaknya, besar dugaan kemungkinan terjadinya kasus infeksi TiLV pada budidaya ikan nila yang ada di Lombok, adalah melalui impor benih. Oleh karena itu, persyaratan dan peraturan yang tegas untuk impor ikan atau udang budidaya harus bebas penyakit. Pada saat ini kasus infeksi TiLV pada ikan nila tenyata suspektif sudah menyebar ke beberapa lokasi budidaya selain di Lombok, TiLV juga menginfeksi di sentra budidaya ikan nila di Medan, Jambi, Bali, Brebes, Jogjakarta, Cirebon, dan beberapa daerah di Jawa Barat (anonim/ personal komunikasi). Penyakit lain yang dapat

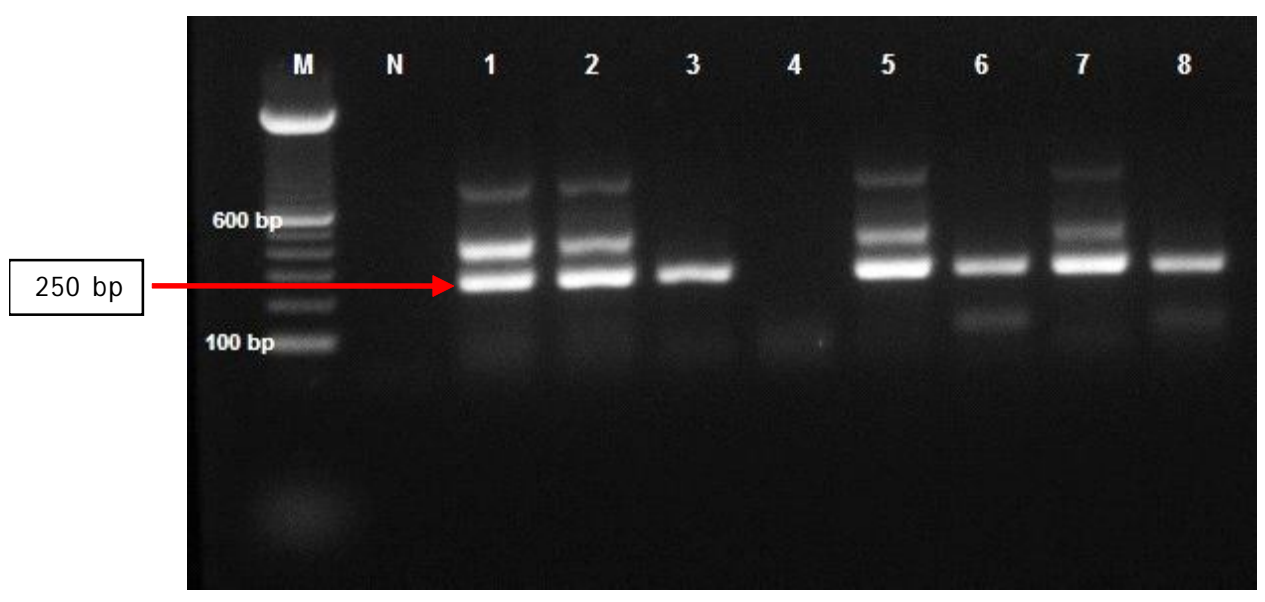

Gambar 3. Hasil amplifikasi nila 0. niloticus strain Anjani semi-nested RT-PCR pada organ uji yang berbeda (N: negatif kontrol; $1 \& 2$ : otak; $3 \& 4$ : hati; $5 \& 6$ : ginjal; 7 \& 8: limpa; M: marker 100 bp DNA ladder).

Figure 3. The result of semi-nested RT-PCR amplification on tilapia fish $\mathbf{0}$. niloticus Anjani strain on different organs tested ( $N$ : negative control; $1 \& 2$ : brain; $3 \& 4$ : heart; $5 \& 6$ : kidney; $7 \&$ 8: spleen; $M: 100$ bp marker of DNA ladder). 
Tabel 3. Hasil analisis semi-nested RT-PCR pada ikan nila 0. niloticus strain Anjani dengan organ uji yang berbeda

Table 3. Result of semi-nested RT-PCR analysis on tilapia fish 0. niloticus Anjani strain with different organs tested

\begin{tabular}{lcc}
\hline & \multicolumn{2}{c}{ Hasil PCR (PCR result) } \\
\cline { 2 - 3 } Organ & \multicolumn{2}{c}{ Primers } \\
\cline { 2 - 3 } & EXT-1 \& ME-1 & ME-1 \& ME-2 \\
& $\mathbf{4 1 5}$ bp & $\mathbf{2 5 0 ~ b p ~}$ \\
\hline Otak-1 (Brain-1) & Positif (Positive) & Positif (Positive) \\
Otak-2 (Brain-2) & Positif (Positive) & Positif (Positive) \\
Hati-2 (Liver-1) & Negatif (Negative) & Positif (Positive) \\
Hati-2 (Liver-2) & Negatif (Negative) & Negatif (Negative) \\
Ginjal-1 (Kidney-1) & Negatif (Negative) & Positif (Positive) \\
Ginjal-2 (Kidney-2) & Negatif (Negative) & Positif (Positive) \\
Limpa-1 (Spleen-1) & Negatif (Negative) & Positif (Positive) \\
Limpa-2 (Spleen-2) & Negatif (Negative) & Positif (Positive) \\
\hline
\end{tabular}

menyerang budidaya ikan nila walaupun kasus ini belum pernah ditemukan di Indonesia adalah infeksi betanoda virus (RNA virus) yang biasa ditemukan pada ikan kakap/ kerapu. Betanoda virus ini menyerang larva ikan nila ukuran 0-7 setelah menetas (post-hatching larvae) dengan gejala adanya kerusakan jaringan pada bagian otak berupa vakuolasi (Bigarre et al., 2009). Secara umum kerugian akibat adanya penyakit khususnya infeksi TiLV mengakibatkan kerugian sosial ekonomi dan dampaknya terhadap ketahanan pangan, tetapi tidak berdampak terhadap kesehatan manusia (Jansen \& Mohan, 2017). Antisipasi untuk menekan penyebaran infeksi TiLV ini adalah dengan melakukan eradikasi, serta sertifikasi kesehatan ikan. Ke depan pencegahan infeksi TiLV pada ikan nila perlu dikembangkan melalui vaksinasi untuk menekan penyebaran penyakit. Pembuatan vaksin dengan cell line culture menjadi pilihan, sehingga dapat meningkatkan produksi ikan nila sebagai sumber devisa negara di Indonesia.

Tabel 4. Perbandingan nukleotida dan sekuen asam amino TiLV Indonesia dengan Israel, Thailand, India, dan Mesir

Table 4. Comparison of nucleotide and amino acid sequences of TiLV Indonesia, Israel, Thailand, India, and Egypt

\begin{tabular}{ccccc}
\hline $\begin{array}{c}\text { Nukleotida yang diperiksa } \\
\text { Examined nucleotides (\%) }\end{array}$ & $\begin{array}{c}\text { Nilai error } \\
\text { Error value }\end{array}$ & $\begin{array}{c}\text { Kemiripan identitas } \\
\text { Similarity identity (\%) }\end{array}$ & $\begin{array}{c}\text { Negara } \\
\text { Country }\end{array}$ & $\begin{array}{c}\text { Inang } \\
\text { Host }\end{array}$ \\
\hline 100 & 0 & 97 & Israel: Sea of Galilee & KU751816 \\
100 & 0 & 97 & Israel: Sea of Galilee & KJ605629 \\
100 & 0 & 97 & Thailand & KY381578 \\
100 & 0 & 97 & India & MF502419 \\
100 & 0 & 96 & India & MF574205 \\
97 & 0 & 97 & India & MF582636 \\
100 & $8 \mathrm{E}-177$ & 95 & Thailand & KX631923 \\
85 & $2 \mathrm{E}-168$ & 98 & Israel & KU552135 \\
58 & $3 \mathrm{E}-101$ & 95 & India & MF574206 \\
59 & $8 \mathrm{E}-92$ & 93 & Egypt; farm-3 & KY817385 \\
59 & $4 \mathrm{E}-90$ & 93 & Egypt; farm-8 & KY817384 \\
48 & $2 \mathrm{E}-83$ & 96 & Israel & KU552139 \\
\hline
\end{tabular}




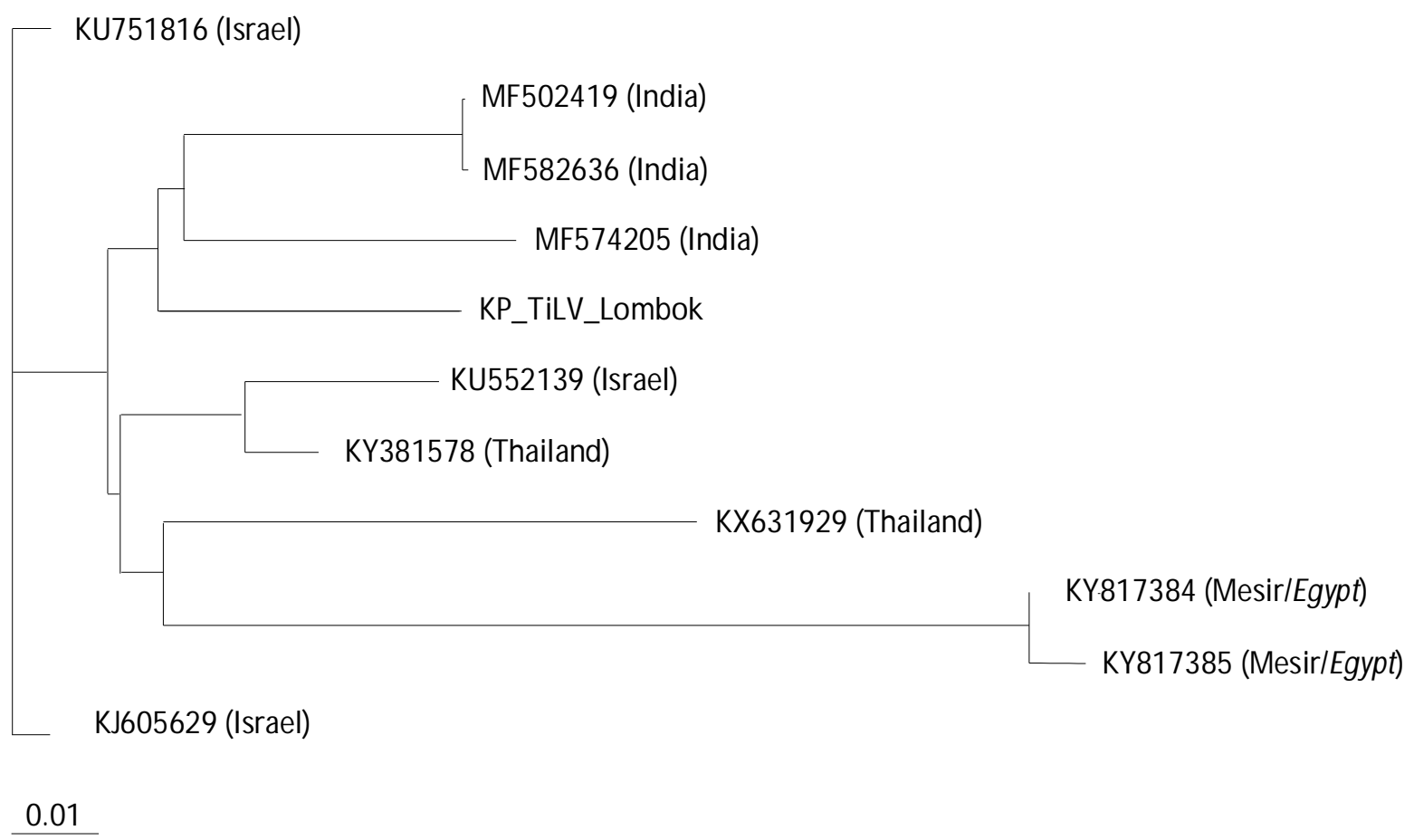

Gambar 4. Gambaran filogenetik berdasarkan urutan nukleotida pada segmen-3 menggunakan software BIOEDIT-MEGA Versi 7, strain antara TiLV asal Lombok (KP TiLV Lombok) (tanda panah) dengan, Israel (KU751816, KJ605629, dan KU552139), Thailand (KY381578 dan KX631923), India (MF502419, MF574205, dan MF582636), Mesir (KY817385 dan KY817384).

Figure 4. Phylogenetic tree showing the relationship based on segmen-3 nucleotide sequence of TiLV using BIOEDIT-MEGA Versi 7 sofware, between strain from Lombok (KP TLV Lombok) (red arrow) to Israel (KU751816, KJ605629, and KU552139), Thailand (KY381578 and KX631923), India (MF502419, MF574205, and MF582636), Egypt (KY817385 and KY817384).

\section{KESIMPULAN}

Kasus kematian massal budidaya ikan nila di Lombok yang telah dideteksi dengan metode seminested RT PCR dan sekuensing menggunakan spesifik primer, secara suspektif disebabkan oleh infeksi TiLV. Sekuen DNA dari TiLV ikan nila Lombok mempunyai kesamaan sebesar 97\%dengan TiLV dari Israel, Thailand, dan India.

\section{UCAPAN TERIMA KASIH}

Terima kasih disampaikan Kepada Balai Karantina Ikan Pengendalian Mutu dan Keamanan Hasil Perikanan Kelas II Mataram yang telah memberi kesempatan untuk mendapatkan sampel uji dan Balai Uji Standar Karantina Ikan Pengendalian Mutu dan Keamanan Hasil Perikanan yang telah memberikan fasilitas pengujian dan analisis sehingga tersusunnya naskah publikasi ini.

\section{DAFTAR ACUAN}

Amal, M.N.A., Koh, C.B, Nurliyana, M., Suhaiba, M., Nor-Amalina, Z., Santh, S., Diyana-Nadhirah, K.P.,
Yusof, M.T., Ina-Salwany, M.Y., \& Zamri-Saad, M. (2017). A case of natural co-infection of Tilapia Lake Virus and Aeromonas veronii in a Malaysian red hybrid tilapia (Oreochromis niloticus $x \quad 0$. mossambicus) farm experiencing high mortality. Aquaculture, 485, 12-16; https://doi.org/10.1016/ j.aquaculture.2017.11.019.

Bacharach, E., Mishra, N., Briese, T., Zody, M.C., Kembou Tsofack, J.E., Zamostiano, R., \& Lipkin, W.I. (2016). Characterization of a Novel Orthomyxo-like Virus Causing Mass Die-Offs of Tilapia. MBio, 7, 1-7.

Beheraa, B.K., Pradhanb, P.K., Swaminathanc, T.R., Soodb, N., Prasenjit Pariaa, Abhishek Dasa, Vermab, D.K., Kumarc, R., Yadavb, M.K., Devb, A.K., Paridaa, P.K., Dasa, B.K., Lalb, K.K., \& Jenad, J.K. (2017). Emergence of Tilapia Lake Virus associated with mortalities of farmed nile tilapia Oreochromis niloticus (Linnaeus 1758) in India. Aquaculture, 484, 168-174; https://doi.org/10.1016/ j.aquaculture. 2017.11.025. 
Bigarre. L., Cabon, J., Baud, M., Heimann, M., Body, A., Lieffrig, F., \& Castric, J. (2009). Outbreak of betanodavirus infection in tilapia, Oreochromis niloticus (L.), in fresh water. Journal of Fish Diseases, 32, 667-673; doi: 10.1111/j.13652761.2009.01037.x.

Dong, H.T., Siriroo, S., Meemetta, W., Santimanawong, W., Gangnonngiw, W., Pirarat, N., Khunrae, K., \& Senapin, S. (2017a). Emergence of tilapia lake virus in Thailand and an alternative semi-nested RT-PCR for detection. Aquaculture, 476, 111-118.

Dong, H.T., Atagubac, G.A., Khunraea, P., Rattanarojponga, T., \& Senapin, S. (2017b). Evidence of TiLV infection in tilapia hatcheries in Thailand from 2012 to 2017 reveals probable global spread of the disease; doi: 10.1016/ j.aquaculture.2017.06.035.

Eyngor, M., Zamostiano, R., Tsofack, J.E.K., Berkowitz, A., Bercovier, H., Tinman, S., \& Eldar, A. (2014). Identification of a Novel RNA Virus Lethal to Tilapia. Journal of Clinical Microbiology, 52, 4137-4146.

Fathi, M., Dickson, C., Dickson, M., Leschen, W., Baily, J., Muir, F., Ulrich, K., \& Weidmann, M. (2017). Identification of Tilapia Lake Virus in Egypt in nile tilapia affected by 'summer mortality' syndrome. Short communication. Aquaculture, 473, 430-432; h t t p://dx.do i.org/10.1016/ j.aquaculture.2017.03.014.

Food and Agriculture Organization [FAO] of the United Nations. (2017a). Global aquaculture production.
Rome: FAO. http://www.fao.org/fishery/statistics/ global-production/en.

Jansen, M.D., \& Mohan, C.V. (2017). Tilapia lake virus (TiLV): Literature review. Penang, Malaysia: CGIAR Research Program on Fish Agri-Food Systems. Working Paper: FISH-2017-04.

Nicholson, P., Fathi, M.A., Fischer, A., Mohan, C., Schieck, E., Mishra, N., \& Jores, J. (2017). Detection of Tilapia Lake Virus in Egyptian fish farms experiencing high mortalities in 2015. Short Comunication. Journal of Fish Disease, p. 1925-1928; doi: 10.1111/jfd.12650.

Senapin, S., Phewsaiya, K., Briggs, M., \& Flegel, T.W. (2007). Outbreaks of infectious myonecrosis virus (IMNV) in Indonesia confirmed by genome sequencing and use of an alternative RT-PCR detection method. Aquaculture, 266, 32-38.

Sunarto, A., \& Cameron, A. (2006). Epidemiology and control of Koi herpes virus in Indonesia. Proceedings of the $11^{\text {th }}$ International Symp. on Vet. Epi and Eco. www.sciquest.org.nz

Surachetpong, W., Janetanakit, T., Nonthabenjawan, N., Tattiyapong, P., Sirikanchana, K., \& Amonsin, A. (2017). Outbreaks of Tilapia Lake Virus Infection, Thailand, 2015-2016. Emerging Infectious Diseases, 23(6), 1031-1033; doi: https://dx.doi.org/ 10.3201/eid2306.161278; www.cdc.gov/eid.

Tsofack, J.E.K., Zamostiano, R., Watted, S., Berkowitz, A., Rosenbluth, E., Mishra, N., \& Bacharach, E. (2016). Detection of Tilapia Lake Virus (TiLV) in clinical samples by culturing and nested RT-PCR. J. Clin. Microbiol.; doi: 10.1128/JCM.01808-16. 